\title{
The role of MET in chemotherapy resistance
}

\author{
Georgina E. Wood $\mathbb{D}^{1} \cdot$ Helen Hockings ${ }^{1} \cdot$ Danielle M. Hilton ${ }^{1} \cdot$ Stéphanie Kermorgant $\mathbb{D}^{1}$
}

Received: 16 July 2020 / Revised: 7 November 2020 / Accepted: 18 November 2020 / Published online: 1 February 2021

(c) The Author(s) 2021. This article is published with open access

\begin{abstract}
Chemotherapy remains the mainstay of treatment in the majority of solid and haematological malignancies. Resistance to cytotoxic chemotherapy is a major clinical problem and substantial research is ongoing into potential methods of overcoming this resistance. One major target, the receptor tyrosine kinase MET, has generated increasing interest with multiple clinical trials in progress. Overexpression of MET is frequently observed in a range of different cancers and is associated with poor prognosis. Studies have shown that MET promotes resistance to targeted therapies, including those targeting EGFR, BRAF and MEK. More recently, several reports suggest that MET also contributes to cytotoxic chemotherapy resistance. Here we review the preclinical evidence of MET's role in chemotherapy resistance, the mechanisms by which this resistance is mediated and the translational relevance of MET inhibitor therapy for patients with chemotherapy resistant disease.
\end{abstract}

\section{Introduction}

The protein MET (also termed Met, c-Met, c-MET), encoded by the proto-oncogene $M E T$ found on chromosome $7 \mathrm{q} 31$, is a cell surface receptor tyrosine kinase (RTK) predominantly expressed by epithelial cells $[1,2]$. Upon binding of its only known ligand, hepatocyte growth factor (HGF), MET homodimerises, phosphorylates and triggers the stimulation of a complex system of intracellular signalling cascades. This leads to the activation of key molecules such as extracellular signal-regulated kinase 1 or 2 (ERK1/2), the phosphoinositide 3-kinase-AKT axis (PI3K/ AKT), signal transducer and activator of transcription 3 (STAT3) and Rac1 [1]. As a consequence, cells increase their proliferation, survival and/or motility. Interestingly, MET activation by its ligand HGF, also triggers rapid MET endocytosis through a dynamin and clathrin mediated pathway [3]. Although most endocytosed MET is degraded, this occurs at a slow pace. MET remains active and triggers

Georgina E. Wood

georgina.wood3@nhs.net

$\bowtie$ Stéphanie Kermorgant

s.kermorgant@qmul.ac.uk

1 Barts Cancer Institute, Queen Mary University of London, John Vane Science Centre, Charterhouse Square, London EC1M 6BQ, UK activation of ERK1/2, STAT3 and Rac1 from within endosomes [3-5], as opposed to the classical view of RTK signalling from the plasma membrane only (Fig. 1). Furthermore, oncogenic forms of MET display modified endocytosis and/or ubiquitination leading to enhanced stability, contributing to their malignant potential [6].

The effects of MET activation are crucial to physiological processes such as embryonic development, organ development and wound healing [7]. HGF is a pleiotropic factor produced by mesenchymal cells in the stroma and as such is widely distributed in the extracellular matrix (ECM) of most tissues [1, 8]. Dysregulation of the MET/HGF pathway leads to uncontrolled cell proliferation and oncogenesis and is observed in multiple tumour types [9]. Germline and somatic mutations in MET's kinase domain leading to constitutive activation are seen in renal papillary carcinoma, childhood hepatocellular carcinoma and colorectal cancer [10-12], whilst intronic mutations leading to an exon 14 deleted splice variant are seen in non-small cell lung cancer (NSCLC) [6]. Increased levels of serum and intra-tumoural HGF are observed in NSCLC and breast cancer $[13,14]$.

MET amplification/overexpression has been shown to lead to dependence on MET for cell survival [15]. An increasing number of MET/HGF-directed therapies aiming to target this oncogene addiction are being developed. There are three tyrosine kinase inhibitors (TKIs) which target MET that are currently approved for use as monotherapy in the treatment of cancers - crizotinib (PF-02341066), 


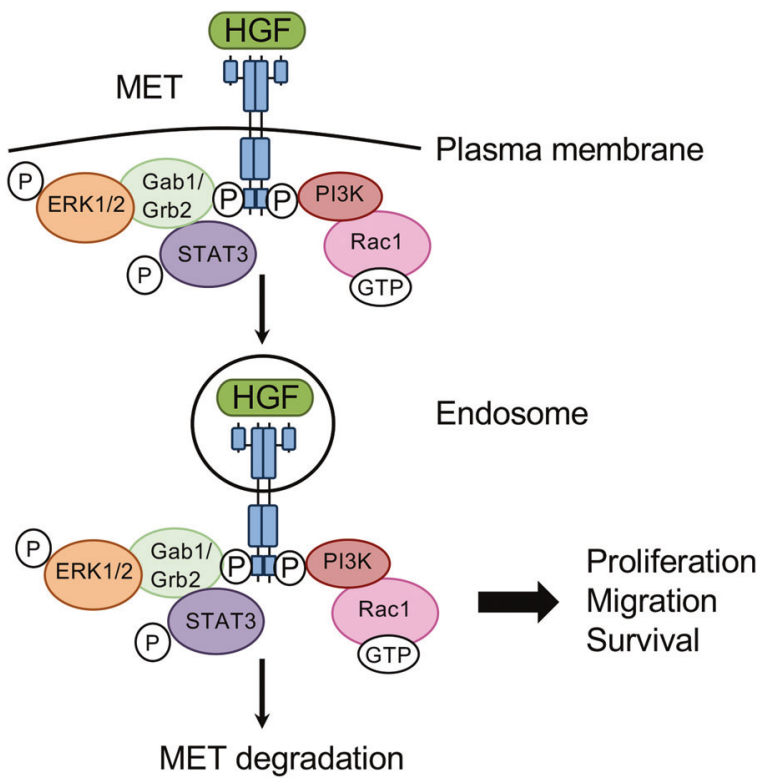

Fig. 1 MET signalling. HGF binding to MET triggers MET dimerisation and phosphorylation. Several signalling pathways are then activated, leading to the activation of signals including ERK1/2, STAT3, PI3K and Rac1. Cells respond in increasing their proliferation, migration and/or survival. In parallel, HGF binding to MET triggers its internalisation. MET is still bound to HGF and continues to signal on endosomes. MET internalisation has been shown to be required to sustain its signalling. MET slowly gets degraded, leading to signal termination but oncogenic MET mutants are protected against degradation and trigger persistent endosomal signalling, contributing to their oncogenicity.

cabozantinib (XL-184) and capmatinib (INC280). Crizotinib and cabozantinib are both multitarget inhibitors, their main targets being ALK, ROS1 and MET for crizotinib, and VEGFRs, AXL, RET and MET for cabozantinib. Capmatinib, a selective MET inhibitor, has recently been FDAapproved for use in advanced NSCLC patients with a MET exon 14 mutation following the GEOMETRY mono-1 trial [16]. Table 1 gives an overview of MET/HGF-directed drugs that have been investigated in preclinical and/or clinical research and highlights those that have progressed to phase III trials. Previous reviews have comprehensively summarised details of all of these studies including a recent review of the most relevant or ongoing studies [17].

As our understanding of the molecular biology of cancer has progressed, drug development has shifted towards a more targeted and personalised approach to treatment. However, despite a growing number of targeted cancer therapies, cytotoxic chemotherapy remains the mainstay of treatment for malignant disease. Different classes of chemotherapy and their clinical uses are outlined in Table 2. Most agents are directed against the processes of DNA replication and mitosis, utilising malignant cells' defective DNA repair pathways and triggering cell death [18]. Some cancer types, such as glioblastoma and pancreatic cancer, are known to be innately chemoresistant and are characterised by a lack of response to initial chemotherapy. The majority of tumours develop acquired chemotherapy resistance, where an initially chemosensitive tumour adapts in response to chemotherapy through various mechanisms including: (i) increased cell viability which can be directly triggered by impaired apoptosis or increased proliferation [19], (ii) improved DNA repair [19], (iii) increased drug efflux and altered drug metabolism [19-21], (iv) propagation of cancer stem cells [22], (v) increased invasive potential [23] and (vi) increased tumour hypoxia with altered angiogenesis [24]. All of these mechanisms can lead to increased cancer cell viability. Often, a combination of these mechanisms is observed in chemoresistant cells.

It is known that MET confers resistance to targeted agents including BRAF inhibitors in malignant melanoma and the EGFR inhibitor gefitinib in NSCLC, through activating oncogenic signalling pathways such as $\mathrm{PI} 3 \mathrm{~K} / \mathrm{AKT}$ [25-27]. This review compiles the recent evidence that MET also promotes resistance to chemotherapeutic agents. Furthermore, MET inhibition reduces the viability of chemoresistant cancer cells and can synergise with chemotherapy. We also explore the molecular mechanisms that could be exploited to overcome MET-driven chemotherapy resistance.

\section{Role of MET in chemoresistance and mechanisms involved}

Recent preclinical studies have shown that MET is involved in the above-cited key mechanisms of chemoresistance, and point towards a synergy between chemotherapy and MET inhibition. The studies use distinct cell lines with differing degrees of chemosensitivity or isogenic pairs of parental and chemoresistant cells. Several studies demonstrate that HGF reduces cell sensitivity to chemotherapy. Others report enhanced MET signalling in the chemoresistant cells compared to the chemosensitive or less resistant cells. This enhanced MET signalling results from: (i) overexpression of MET [28-36], (ii) constitutive activation of MET [28, 29, 37], (iii) activation sustained by $\operatorname{HGF}[30,37]$, and (iv) secretion of HGF, not normally expressed by epithelial cells, leading to an autocrine activation loop [28, 33, 34, 37]. Interestingly, a number of studies also found HGF to already be secreted by chemosensitive cells $[28,29,32,37-40]$. It is possible that this pre-existing HGF plays a role in the acquisition of chemoresistance, although this remains to be determined. We describe below the results of these studies. The following experimental details from each study are presented in Table 3: cancer type, chemotherapy agent tested, cell models used (divided by chemosensitive and chemoresistant cell lines), method of 
Table 1 A summary of the drugs that have been developed to target the MET/HGF signalling pathway and their use in clinical trials, with a focus on those which have reached Phase III (completed or ongoing).

\begin{tabular}{|c|c|c|}
\hline & Inhibitor name & Phase III ongoing-completed \\
\hline \multirow{4}{*}{$\begin{array}{l}\text { Anti-HGF monoclonal } \\
\text { antibodies }\end{array}$} & Rilotumumab/AMG-102 & NCT02154490 \\
\hline & Ficlatuzumab/AV-299/SCH 900105 & Not yet conducted - trials completed and ongoing at Phase 2 \\
\hline & HuL2G7/TAK701 & Not yet conducted - trial completed at Phase 1, none ongoing \\
\hline & YYB-101 & Not yet conducted - trials completed at Phase 1 and ongoing at Phase 2 \\
\hline \multirow[t]{5}{*}{ MET antagonists } & $\begin{array}{l}\text { Onartuzumab/RO5490258/PRO- } \\
142966\end{array}$ & NCT02488330, NCT01662869, NCT01887886, NCT02031744 \\
\hline & SAIT301 & Not yet conducted - trial completed at Phase 1 , none ongoing \\
\hline & Emibetuzumab/LY2875358/LA480 & Not yet conducted - trials completed and ongoing at Phase 2 \\
\hline & $\begin{array}{l}\text { Amivantamab/JNJ-61186372/ } \\
\text { JNJ-372 }\end{array}$ & NCT04487080 \\
\hline & ABT-700/h224G11 & Not yet conducted - trials completed at Phase 1 and ongoing at Phase 2 \\
\hline \multirow[t]{10}{*}{ MET kinase inhibitors } & Tivantinib/ARQ 197 & NCT02029157, NCT01755767, NCT01244191 \\
\hline & $\begin{array}{l}\text { Savolitinib/AZD6094/HMPL-504/ } \\
\text { HMP-504/Volitinib }\end{array}$ & NCT03091192 \\
\hline & $\begin{array}{l}\text { Tepotinib/MSC2156119J/ } \\
\text { EMD1214063 }\end{array}$ & Not yet conducted - trials completed at Phase 1 and ongoing at Phase 2 \\
\hline & Glesatinib/MGCD265 & Not yet conducted - trials completed and ongoing at Phase 2 \\
\hline & Capmatinib/INC280 & NCT04427072, NCT03784014 \\
\hline & PHA665752 & Not yet conducted - no trials completed at any Phase \\
\hline & SU11274 & Not yet conducted - no trials completed at any Phase \\
\hline & Foretinib/GSK1363089/ XL880 & Not yet conducted - trials completed and ongoing at Phase 2 \\
\hline & Merestinib/LY2801653 & Not yet conducted - trials completed at Phase 1 and ongoing at Phase 2 \\
\hline & MK8033 & Not yet conducted - trial completed at Phase 1 , none ongoing \\
\hline \multirow[t]{3}{*}{ Multi-kinase inhibitors } & $\begin{array}{l}\text { Crizotinib/PF-02341066 } \\
\text { Targets: } M E T, A L K, \text { ROS, RON }\end{array}$ & $\begin{array}{l}\text { NCT02838420, NCT02075840, NCT01639001, NCT00932893, } \\
\text { NCT01154140, NCT04009317, NCT03052608, NCT02737501, } \\
\text { NCT02767804, NCT02201992, NCT03194893, NCT03126916, } \\
\text { NCT03596866, NCT03874273 }\end{array}$ \\
\hline & $\begin{array}{l}\text { Cabozantinib/XL184, BMS } 907351 \\
\text { Targets: } M E T, \text { VEGFR2, KIT, RET, } \\
\text { AXL, FLT3 }\end{array}$ & $\begin{array}{l}\text { NCT01908426, NCT01605227, NCT01865747, NCT00704730, } \\
\text { NCT03690388, NCT04338269, NCT03755791, NCT03937219, } \\
\text { NCT03375320, NCT04446117, NCT03793166, NCT03729245, } \\
\text { NCT03141177, NCT04211337 }\end{array}$ \\
\hline & $\begin{array}{l}\text { Amuvatinib/MP470 } \\
\text { Targets: MET, c-Kit, PDGFR } \alpha, \text { Flt3, } \\
\text { c-Ret }\end{array}$ & Not yet conducted - trial completed at Phase 2, none ongoing \\
\hline
\end{tabular}

MET/HGF blockade employed, observed changes in MET/HGF leading to enhanced MET signalling and the MET-dependent mechanisms of chemotherapy resistance. Figure 2 illustrates the mechanisms of MET-driven chemoresistance reported in these studies.

\section{MET increases cell viability through reducing apoptosis and/or increasing proliferation in chemoresistant cells}

Multiple studies report that the observed enhanced MET signalling occurring in chemoresistant cells increases their viability. This occurs through a decrease in apoptosis, as shown in most studies, but also through stimulation of proliferation. Proliferative activity is a vital component of cancer development and progression, with the MET/HGF axis being a known molecular regulator. Apoptosis, the principal route of cell death triggered in response to chemotherapy, is regulated by a multitude of different factors. One important group is the $\mathrm{Bcl}$ family of proteins, including Bcl-2, Bcl-XL and Bad. MET has been shown to influence the regulation of pro-apoptotic and anti-apoptotic factors to promote cell survival or proliferation through activating many signalling pathways including the Mitogen-Activated Protein Kinase (MAPK) cascade such as ERK1/2, Jun amino-terminal kinases (JNKs), p38, PI3K-AKT and STAT3 [41, 42]. On phosphorylation, AKT promotes cell survival pathways mediated by Bcl-2 and Bcl-XL [43].

Several studies have reported the protective effect of HGF against chemotherapy-induced cell death or the effect 
Table 2 An overview of chemotherapeutic agents, their mechanism of action and indication.

\begin{tabular}{|c|c|c|c|c|}
\hline Class of chemotherapy & Subtype & Drugs & Mechanism of action & Indication \\
\hline \multirow[t]{5}{*}{ Alkylating agents } & Nitrogen mustards & $\begin{array}{l}\text { Cyclophosphamide, Melphalan, Ifosfamide, } \\
\text { Chlorambucil, Busulfan }\end{array}$ & \multirow{5}{*}{$\begin{array}{l}\text { Alkylate proteins, RNA and } \\
\text { DNA. Covalently bind to DNA } \\
\text { via alkyl group causing intra } \\
\text { and interstrand cross-links }\end{array}$} & $\begin{array}{l}\text { Multiple myeloma, sarcoma, } \\
\text { breast cancer, lymphoma }\end{array}$ \\
\hline & Nitrosoureas & Carmustine, Lomustine, Stretozotocin & & Glioblastoma multiforme \\
\hline & Tetrazines & Dacarbazine, Temozolamide & & $\begin{array}{l}\text { Glioblastoma multiforme, } \\
\text { Hodgkin's lymphoma }\end{array}$ \\
\hline & Aziridines & Mytomycin & & Gastric cancer \\
\hline & Platinums & Cisplatin, Carboplatin, Oxaliplatin & & $\begin{array}{l}\text { Ovarian, gastric, lung, head and } \\
\text { neck cancer, sarcoma }\end{array}$ \\
\hline Antimetabolites & Anti-folates & Methotrexate, Pemetrexed & $\begin{array}{l}\text { Inhibit enzymes essential for } \\
\text { thymidylate and purine } \\
\text { production }\end{array}$ & Lung cancer, sarcoma \\
\hline \multirow[t]{2}{*}{ Antimicrotubule agents } & Vinca alkaloids & Vincristine, Vinblastine, Vinorelbine & $\begin{array}{l}\text { Bind to tubulin inhibiting } \\
\text { assembly into microtubules }\end{array}$ & Lung cancer \\
\hline & Taxanes & Docetaxel, Paclitaxel & $\begin{array}{l}\text { Promote microtubule stability, } \\
\text { preventing disassembly }\end{array}$ & Breast, ovarian cancer \\
\hline \multirow[t]{2}{*}{$\begin{array}{l}\text { Topoisomerase } \\
\text { inhibitors }\end{array}$} & $\begin{array}{l}\text { Topoisomerase I } \\
\text { inhibitors }\end{array}$ & Irinotecan, Topotecan, Camptothecin & \multirow{2}{*}{$\begin{array}{l}\text { Block unwinding of the DNA } \\
\text { double strand helix and prevent } \\
\text { DNA synthesis and translation }\end{array}$} & Lung cancer, colorectal cancer \\
\hline & $\begin{array}{l}\text { Topoisomerase II } \\
\text { inhibitors }\end{array}$ & Etoposide, Doxorubicin & & Lung cancer, sarcoma \\
\hline \multirow[t]{2}{*}{ Cytotoxic antibiotics } & Anthracyclines & Doxorubicin, Epirubicin & \multirow{2}{*}{$\begin{array}{l}\text { Intercalates DNA, } \\
\text { topoisomerase II inhibitor, } \\
\text { generate reactive oxygen } \\
\text { species (ROS), DNA adduct } \\
\text { formation }\end{array}$} & $\begin{array}{l}\text { Breast cancer, } \\
\text { oesophageal cancer }\end{array}$ \\
\hline & Bleomycins & Bleomycin & & $\begin{array}{l}\text { Hodgkin's lymphoma, } \\
\text { testicular cancer }\end{array}$ \\
\hline
\end{tabular}

of MET inhibition/loss of expression in reducing chemoresistance.

\section{HGF decreases cells' sensitivity to chemotherapy through reducing apoptosis}

Exogenous HGF [39, 44-48] or endogenous HGF present in the conditioned media of cancer associated fibroblasts (CAFs) [38], has been shown to protect breast, glioblastoma, lung, ovarian cancer and osteosarcoma cells against apoptosis induced by the DNA damaging agents doxorubicin, cisplatin, camptothecin or paclitaxel.

The mechanisms reported were: (i) prevention of the downregulation of Bcl-X $\mathrm{L}_{\mathrm{L}}$; [44, 47] (ii) activation of ERK1/2 and the PI3K/AKT-dependent anti-apoptotic pathway; $[38,39,48]$ (iii) activation of focal adhesion kinase (FAK) [46] and (v) reduction of apoptosis-inducing factor (AIF) expression [46]. AIF is a protein located within the mitochondria, whose activation leads to a caspase-independent pathway of apoptosis by mediating DNA fragmentation and chromatin condensation [49]. Another reported mechanism is the induction of expression of the molecular chaperone protein GRP78 (BiP) [38]. BiP has been reported to inhibit apoptosis by interactions with caspase-7 or p53 [28, 38], and through preventing the release of cytochrome $\mathrm{c}$ by binding to BIK and BAX [50, 51].

Interestingly, the expression of HGF (through HGF cDNA transfection) in Chinese hamster ovary cells reduced their sensitivity to chemotherapy [52]. Moreover, an autocrine loop of MET activation has been reported in several chemoresistant cancer cell lines, leading to their increased viability [2, 28, 37]. For example, Lasagna et al. reported that a multi-drug resistant (MDR) hepatocellular carcinoma (HCC) cell line secreted higher levels of HGF than the isogenic parental cell line, enhancing their proliferative activity [34].

\section{Chemoresistant cells display enhanced MET signalling and MET-targeted therapy reduces their survival by increasing apoptosis and/or decreasing proliferation}

Several studies have shown that MET expression and/or activation is increased in cells with acquired chemoresistance compared to their isogenic parental cell lines. This in turn leads to an increase in MET signalling with enhanced sensitivity to MET inhibition and reversal of chemoresistance.

For example, cisplatin-resistant ovarian cancer cell lines were found to express high levels of MET compared to parental chemosensitive cells. On treatment with cisplatin, MET phosphorylation was increased, but upon MET inhibition with PHA-665752 or MET siRNA knockdown cisplatin-induced apoptosis was enhanced [30]. In a similar way, treatment of osteosarcoma cell lines with PHA-665752 or with a neutralising anti-HGF antibody enhanced the cytotoxic effect of cisplatin [45].

Small cell lung cancer (SCLC) cells with acquired chemoresistance to paclitaxel, cisplatin or SN38 [28], MDR multiple myeloma cell lines [29], MDR uterine sarcoma and breast cancer cell lines (that overexpress ABCB1/MDR1) 
Table 3 Table of all the preclinical studies evidencing the role of MET in chemoresistance and the mechanisms involved.

\begin{tabular}{|c|c|c|c|c|c|c|}
\hline \multirow{2}{*}{ Cancer } & \multirow{2}{*}{ Chemotherapy } & \multicolumn{2}{|c|}{ Cell model } & \multirow{2}{*}{ MET/HGF blockade used } & \multirow{2}{*}{ Functions } & \multirow{2}{*}{ Refs } \\
\hline & & Chemosensitive & Chemoresistant & & & \\
\hline \multirow{7}{*}{ Ovarian } & Paclitaxel & SKOV 3 and OVCAR-3 & $\mathrm{n} / \mathrm{a}$ & Capmatinib $(2,4,6,8 \mu \mathrm{M})$ & $A, R, C C$ & [54] \\
\hline & Cisplatin & SKOV 3 and $3 \mathrm{AO}$ & OVCAR3, OV & PHA665752 (400 nM), KD & A & {$[30]$} \\
\hline & Doxorubicin & A2780 & A2780DR 0 & SU11274 $(1$ or $2 \mu \mathrm{M}), \mathrm{KD}$ & $\mathrm{DE}$ & [32] \\
\hline & Carboplatin + paclitaxel & Multiple & $\mathrm{n} / \mathrm{a}$ & MK8033 (8.5-19.2 $\mu \mathrm{M})$ & $\mathrm{P}$ & [53] \\
\hline & Paclitaxel & SKOV3 and $\mathrm{HO}-8910$ & $\mathrm{n} / \mathrm{a}$ & Capmatinib $(60 \mathrm{nM})$ & A & {$[38]$} \\
\hline & Paclitaxel and cisplatin & $\mathrm{CaOV}-3$ and SKOV-3 & $\mathrm{n} / \mathrm{a}$ & KD & A & {$[48]$} \\
\hline & Cisplatin & A2780 and SKOV3 & $\mathrm{n} / \mathrm{a}$ & Crizotinib (1 or $3 \mu \mathrm{M})$ & A & [55] \\
\hline \multirow{4}{*}{ NSCLC } & Cisplatin & $\begin{array}{c}\mathrm{H} 23, \mathrm{H} 226, \mathrm{H} 838, \mathrm{H} 1437 \\
\mathrm{H} 2009, \mathrm{H} 2087, \mathrm{~A} 549\end{array}$ & $n / a$ & $n / a$ & A & [46] \\
\hline & Cisplatin & H1299 & & miR-206 mimic, KD & $E, D$ & [31] \\
\hline & Cisplatin & A549 & & SU11274 $(0.5 \mu \mathrm{M}), \mathrm{KD}$ & $\mathrm{E}, \mathrm{D}$ & [31] \\
\hline & Cisplatin & A549 & A549/DD & Salvianolic acid A $(10-20 \mu \mathrm{g} / \mathrm{ml}), \mathrm{KD}$ & $\mathrm{A}, \mathrm{R}, \mathrm{D}$ & {$[35]$} \\
\hline \multirow[b]{2}{*}{ SCLC } & Etoposide & $\mathrm{H} 69$ & $\mathrm{H} 69 \mathrm{M}$ & Crizotinib (200 nM) & $E$ & {$[37]$} \\
\hline & Cisplatin, SN-38, paclitaxel & $\mathrm{PC}-6, \mathrm{NCl}-\mathrm{H} 69$ & $\begin{array}{c}\mathrm{PC}-6 / \mathrm{SN}-28, \mathrm{PC}-6 / \mathrm{CDDP}, \\
\mathrm{PC}-6 / \mathrm{TXL}, \mathrm{H} 69 / \mathrm{TXL}\end{array}$ & SU11274 ( 0.5 or $2 \mu \mathrm{M}), \mathrm{KD}$ & A & [28] \\
\hline \multirow{3}{*}{ PDAC } & Gemcitabine & Orthotopic. KPC in vivo & $\mathrm{n} / \mathrm{a}$ & Capmatinib (1mg/kg), KD & $\mathrm{A}$ & [57] \\
\hline & Gemcitabine & BxPc-3 & BXPc-3-GEM & Cabozantinib $(10 \mu \mathrm{M})$ & $A, S$ & [72] \\
\hline & Gemcitabine & Capan-1 & & Crizotinib $(1.5 \mu \mathrm{M})$ & $A, S, E, C$ & [36] \\
\hline \multirow{3}{*}{ Gastric } & SN38 & $\begin{array}{l}\text { OCUM-2M, OCUM-2D, } \\
\text { OCUM-2MD3 }\end{array}$ & $\begin{array}{l}\text { OCUM-2M/SP, OCUM- } \\
\text { 2D/SP, OCUM-2MD3/SP }\end{array}$ & SU11274 (2 $\mu \mathrm{M})$ & $A, S, D$ & [67] \\
\hline & Cisplatin & SGC7901 & SGC7901/DDP & exosome-delivered KD & A & [61] \\
\hline & Doxorubicin & GTL-16 & $\mathrm{n} / \mathrm{a}$ & PHA665752 (0-300 nM) & $A, R$ & [56] \\
\hline Osteosarcoma & Cisplatin & SAOS-2 & $\mathrm{n} / \mathrm{a}$ & PHA665752 $(1 \mu \mathrm{M})$, anti-HGF ab & $A, R$ & {$[45]$} \\
\hline \multirow{2}{*}{ Multiple myeloma } & Melphalan + doxorubicin & RPMI-8226 & RPMI-8226.R5 & SU11274 $(0-1 \mu \mathrm{mol} / \mathrm{L})$ & $A, E$ & \\
\hline & Doxorubicin & U266 & $\mathrm{n} / \mathrm{a}$ & $\mathrm{KD}$ & A & {$[60]$} \\
\hline \multirow{4}{*}{$\begin{array}{l}\text { Glioma/ } \\
\text { Glioblastoma }\end{array}$} & Paclitaxel & U251, SHG44 & $\mathrm{n} / \mathrm{a}$ & antisense deoxynucleotides & A & [59] \\
\hline & Temozolamide & $\mathrm{H} 4, \mathrm{U} 87$ & $\mathrm{n} / \mathrm{a}$ & $\mathrm{KD}$ & & [58] \\
\hline & Doxorubicin, cisplatin, paclitaxel & U-373 & $\mathrm{n} / \mathrm{a}$ & KD & A & [39] \\
\hline & Temozolamide & U251, U87 & $\mathrm{n} / \mathrm{a}$ & SU11274 $(5 \mu \mathrm{M}), \mathrm{KD}$ & $\mathrm{AE}, \mathrm{H}$ & {$[40]$} \\
\hline \multirow{4}{*}{$\begin{array}{c}\text { Breast } \\
\text { adenocarcinoma }\end{array}$} & Doxorubicin & MDA-MB-453, MDA-MB-231 & $\mathrm{n} / \mathrm{a}$ & NK1 $(300 \mathrm{ng} / \mathrm{ml})$ & A & {$[44]$} \\
\hline & Doxorubicin & MDA-MB-453, T47D & $\mathrm{n} / \mathrm{a}$ & Absence of HGF & $A, R$ & {$[47]$} \\
\hline & Doxorubicin & MDA-MB-231 & $\mathrm{n} / \mathrm{a}$ & SU11274 $(1$ or $2 \mu \mathrm{M}), \mathrm{KD}$ & $\mathrm{D}$ & [32] \\
\hline & Doxorubicin & MCF-7 & & $\mathrm{KD}$ & A & [33] \\
\hline $\mathrm{HCC}$ & Doxorubicin & P5 cells & $0.5)$ & Anti-HGF ab & A & $34]$ \\
\hline Colon carcinoma & Doxorubicin & HT29 & & SU11274 ( 1 or $2 \mu \mathrm{M}), \mathrm{KD}$ & $\mathrm{D}$ & {$[32]$} \\
\hline Uterine sarcoma & Doxorubicin & MES-SA & & $\mathrm{KD}$ & A & {$[33]$} \\
\hline Prostate carcinoma & Doxorubicin & DU-145 & $\mathrm{n} / \mathrm{a}$ & Absence of HGF & $A, R$ & {$[47]$} \\
\hline
\end{tabular}

Cell lines in blue font: paired isogenic chemosensitive and chemoresistant cell lines. (Note - some cell lines placed in the chemosensitive category in this table have also been used as a model to study chemoresistance as their chemosensitivity may be reduced). Red box: MET overexpressed in chemoresistant cell line compared to parental cells. Yellow box: constitutive activation of MET. Orange box: MET overexpressed and constitutively active. Green dot: HGF expressed. The darker or lighter green indicate an increase or a decrease of HGF in chemoresistant cells versus chemosensitive cells.

MET-stimulated cellular functions which promote chemoresistance: A: apoptosis inhibition, R: DNA repair enhancement, CC: cell cycle progression, D: drug efflux, P: increased proliferation, E: increased EMT, S: enhanced cancer stem cells survival and proliferation, AE: altered endothelial cell behaviour, $\mathrm{H}$ : increased intra-tumoural hypoxia.

NSCLC non-small cell lung cancer, SCLC small cell lung cancer, PDAC pancreatic ductal adenocarcinoma, $H C C$ hepatocellular carcinoma.

[33] were found to display higher levels of MET protein expression and phosphorylation than their respective isogenic parental cells. The viability of chemoresistant cells was significantly reduced upon treatment with the MET inhibitor SU11274 [28, 29], MET siRNA [28] or MET shRNA [33] knockdown. This occurred through reduced proliferation [29] or enhanced apoptosis [28, 29, 33] as evidenced by the detection of cleaved PARP $[28,33]$ or increased caspase $3 / 7$ activity and annexin V staining [33]. The MET gene was found to be amplified in chemoresistant SCLC cells [28], which could explain MET protein overexpression. Some studies have found that chemoresistant cells express higher levels of HGF versus their isogenic chemosensitive parental cells which likely explains the basal MET phosphorylation [28, 33]. This indicates a switch to autocrine MET activation, which could play a major role in the acquisition of chemotherapy resistance. Patient-derived multiple myeloma plasma cells were found to have higher MET expression and basal phosphorylated MET in patients at disease relapse compared to those at diagnosis or in remission. SU11274 reduced the viability of plasma cells from relapsed, chemoresistant patients [29]. Interestingly, the growth of tumour xenografts formed by ABCB1/MDR1-overexpressed MDR uterine sarcoma and breast cancer cell lines, knocked down for MET with shRNA, was reduced compared to tumours formed by control shRNA transfected cells [33].

These studies demonstrate that MET signalling is enhanced in various chemoresistant cell lines and that MET inhibition can reverse chemotherapy resistance. 


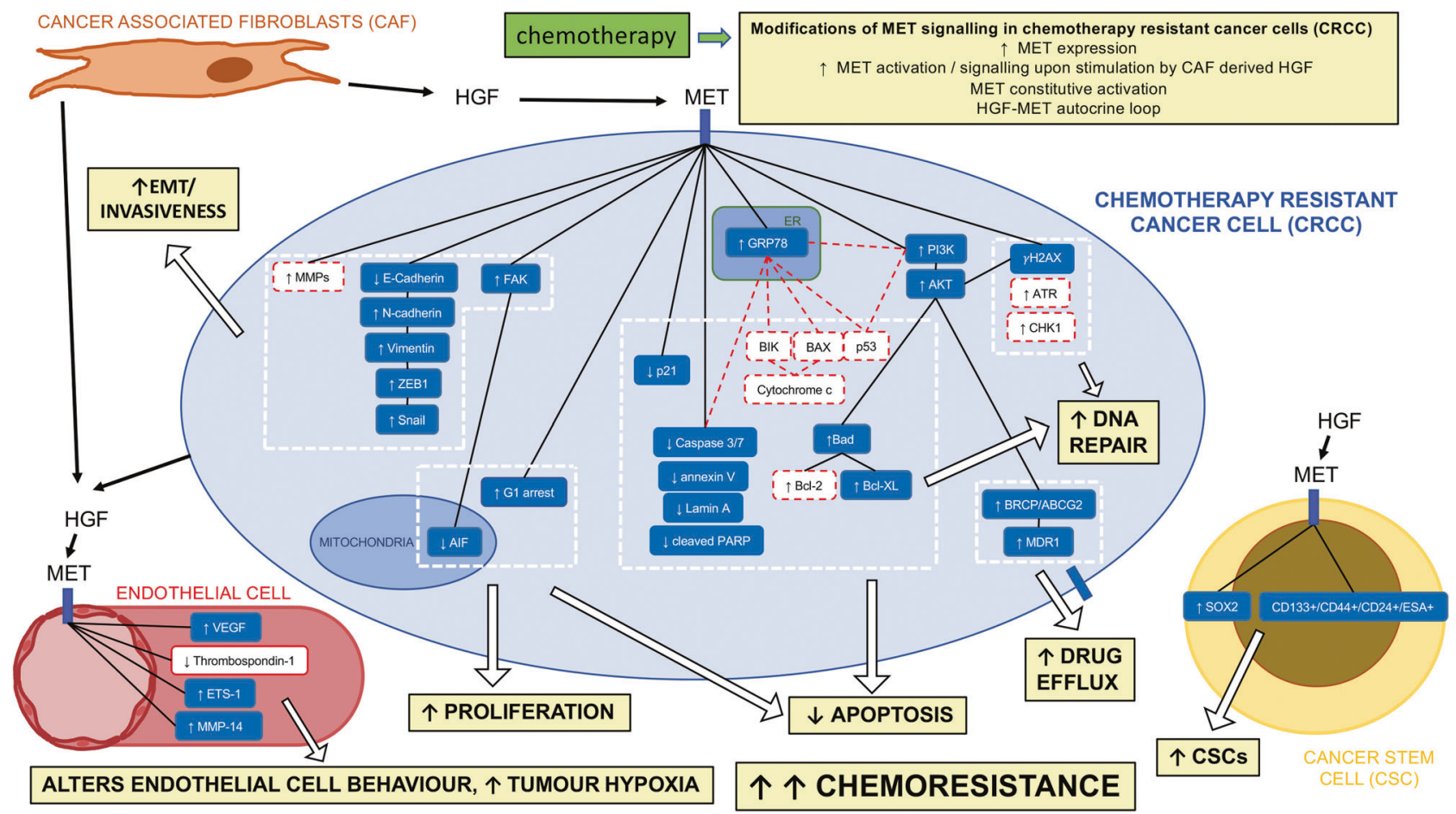

Fig. 2 Model of MET-driven chemoresistance. Chemotherapy resistant cancer cells (CRCC) have altered MET signalling, including overexpression of MET, activation sustained by HGF secreted by CAFs (cancer associated fibroblasts), constitutive activation of MET and secretion of HGF which is not normally expressed by epithelial cells, leading to an autocrine activation loop. This diagram illustrates the effect of this altered MET signalling on: (i) the behaviour of CRCCs: reduction of apoptosis, increased proliferation, enhanced DNA repair, upregulation of drug efflux and stimulation of epithelial-mesenchymal transition; (ii) changes in the tumour microenvironment: alteration of the behaviour of endothelial cells and increased intra-tumoural hypoxia, promotion of cancer stem cells (CSCs) survival and proliferation. All these changes contribute to the development of chemotherapy resistance. The intracellular pathways reported or suggested are shown. Blue box/black line: confirmed mechanism. Dotted red box/red line: proposed mechanism. MMPs matrix metallopeptidases, VEGF vascular endothelial growth factor, AIF apoptosis-inducing factor, ER endoplasmic reticulum.

\section{Pharmacological inhibition or genetic silencing of MET synergises with chemotherapy through reducing apoptosis}

A number of preclinical studies have demonstrated that MET inhibition is able to reverse chemotherapy resistance in various different tumour types.

A synergy between MET inhibition (using MK8033 [53], capmatinib [54], crizotinib [55], PHA-665752 [30, 45, 56] or SU11274 [29]) and chemotherapy (carboplatin [53], paclitaxel [53, 54], cisplatin [30, 45, 55], doxorubicin [29, 56] or bortezomib [29]) has been reported in ovarian [53-55], gastric [56], osteosarcoma [45] and MDR multiple myeloma [29] cancer cell lines. Many of these cell lines were found to exhibit constitutive MET activation [29, 30, 54, 56] and increased MET expression [29]. Cell viability was reduced due to apoptosis induction, evidenced by upregulation of the enzymatic activity of caspase- 3 and of the expression of cleaved caspase- 3 and cleaved lamin A [30, 54-56]. Such synergy was also observed in vivo, with crizotinib and cisplatin combination treatment reducing ovarian tumour growth more than either therapy alone [55]. Interestingly, in several ovarian cancer cell lines, enhanced sensitivity to carboplatin and paclitaxel with MET inhibition (MK8033) has been correlated with a 47 gene signature. Furthermore, the expression of these genes in patient samples was associated with overall survival [53], suggesting that this signature may be utilised as a prognostic biomarker.

In the genetic PDAC mouse model KPC (K-ras ${ }^{\text {LSL.G12D/+ }}$; $\mathrm{p} 53^{\mathrm{R} 172 \mathrm{H} /+}$; PdxCre mice) and orthotopic transplantation of KPC derived cells, MET inhibition with capmatinib sensitised PDAC tumours to gemcitabine, resulting in a reduction in primary tumour volume and metastatic burden via increased apoptosis [57].

In addition to pharmacological inhibition, genetic silencing of MET has been shown to reverse chemoresistance in different tumour types. In several glioma cell lines [58, 59] and in a multiple myeloma cell line [60], the reduction of MET expression by shRNA-mediated knockdown [58, 60] or antisense oligodeoxynucleotides [59] enhanced the effect of temozolamide [58], paclitaxel [59] or doxorubicin [60], in reducing cell survival. This was proposed to be via increased apoptosis with a higher apoptotic cell count [59] or higher levels of cleaved caspase 3 fragments and cleaved 
PARP [60] with the combination treatment compared to either monotherapy. Moreover, low MET expression in glioma patient samples was shown to be associated with enhanced response to alkylating chemotherapy agents and prolonged overall survival [58].

Exosome-delivered MET-specific siRNA (exo-si-c-Met) reversed resistance to cisplatin in gastric cancer cells in vivo and in vitro [61]. In vitro, exo-si-c-Met was shown to promote apoptosis in chemoresistant but not isogenic chemosensitive cells. In vivo, exo-si-c-Met combined with cisplatin treatment had a synergistic effect, reducing growth of chemoresistant tumours [61].

These studies highlight the importance of pursuing combination therapy with MET inhibition and chemotherapy in clinical trials.

\section{MET enhances DNA repair via promoting the chemotherapy-induced DNA damage response}

DNA damage can be caused by exogenous and endogenous sources. Endogenous examples include the production of reactive oxygen species (ROS), produced as a natural byproduct of normal metabolism, whilst exogenous sources include ionising radiation and chemotherapy. The pathways employed in DNA repair include base excision repair (BER), nucleotide excision repair (NER), mismatch repair (MMR), homologous recombination (HR) and non-homologous endjoining (NHEJ). These are commonly dysregulated in cancer in order to facilitate tumorigenesis [62]. The DNA damage response is activated by three main kinases, ATM, ATR and DNA-PK [63].

Studies have shown that repair of chemotherapy-induced DNA damage can be inhibited by MET activation or inhibition. HGF stimulation of breast and prostate cancer cells was shown to enhance the rate of repair of DNA double strand breaks (DSBs) in response to doxorubicin [47]. Interestingly, Bcl-XL, whose downregulation was blocked by HGF, was shown to enhance DNA repair, although it is normally recognised as an anti-apoptotic protein [47].

Conversely, in ovarian [54] and gastric [56] cancer cell lines that display basal MET phosphorylation, MET inhibition with capmatinib [54] or PHA-665752 [56], in combination with paclitaxel [54] or adriamycin [56], has been shown to lead to accumulation of DSBs compared to chemotherapy alone. This was demonstrated by increased levels of the DNA damage response protein $\gamma \mathrm{H} 2 \mathrm{AX}[54,56]$. As well as increasing $\gamma \mathrm{H} 2 \mathrm{AX}$ levels, PHA665752 was shown to trigger $\gamma \mathrm{H} 2 \mathrm{AX}$ tyrosine phosphorylation and its subsequent association with pro-apoptotic kinase JNK1 [56]. $\gamma \mathrm{H} 2 \mathrm{AX}$ tyrosine phosphorylation has also been shown to hinder histones' capacity to interact with DNA repair effectors following DSBs. Destabilisation of the ATR-CHK1-CDC25B DNA damage response pathway was also detected with PHA-665752, with decreased levels of phosphorylated ATR and CHK1 [56]. This would allow cells with damaged DNA to progress through the cell cycle, at which point DSBs and detrimental chromosomal aberrations would trigger apoptosis.

These studies indicate that MET is able to protect cancer cells against the chemotherapy-induced DNA damage response and hence MET inhibition can suppress DNA repair.

\section{MET upregulates drug efflux}

ATP-binding cassette (ABC) transporters are crucial transport proteins which regulate the removal of substances from the cell through the plasma membrane in an ATP-dependent process [64]. Altered drug efflux is a well-recognised mechanism of drug resistance in cancer. For example, overexpression of the $\mathrm{BRCP} / \mathrm{ABCG} 2$ transporter is associated with resistance to several anti-cancer drugs including doxorubicin, mitoxantrone and topotecan [65], whilst ABCB1/MDR1 is frequently overexpressed in drugresistant cell lines and is found to correlate with poor overall survival in patients $[20,66]$.

MET can upregulate the expression of efflux transporters in the cell membrane, thus reducing the intracellular concentration of the chemotherapeutic agent. MET overexpression was shown to trigger an increase of $\mathrm{BRCP} /$ ABCG2 and ABCB1/MDR1 expression in doxorubicinresistant (DR) ovarian carcinoma cells [32] and in cisplatinresistant NSCLC cell lines [31] respectively. Consistent with these findings, MET and ABCB1/MDR1 were overexpressed in MDR uterine sarcoma and breast cancer cell lines, compared to their isogenic parental cell lines [33]. It is thought that MET controls BRCP/ABCG2 at the transcription level via PI3K/AKT activation [32]. MET inhibition with SU11274 and silencing MET by shRNA repressed BRCP/ABCG2 [32] and ABCB1/MDR1, leading to enhanced chemosensitivity [31]. SU11274 was also reported to act in synergy with SN38 in reducing the expression of BRCP/ABCG2 in gastric cancer stem cells [67].

Thus MET overexpression can promote an increase in drug efflux through regulating the expression of efflux transporters, leading to chemoresistance and increased cell survival.

\section{MET promotes the survival and proliferation of chemoresistant cancer stem cells}

Cancer stem cells (CSCs) are thought to generate differentiated tumour cells, which have limited proliferative potential, and are responsible for seeding tumour populations [68]. CSCs have been heavily implicated in mediating chemoresistance in many cancers, including glioblastomas, pancreatic and colorectal cancers [22]. This is thought to be secondary to the cells' ability to lie dormant, increase DNA 
repair and drug efflux capacity, and decrease apoptosis. Thus, CSCs persist through chemotherapy treatment and facilitate relapse through repopulation after treatment has been discontinued. CSCs are characterised differently depending on their tissue of origin, but some common markers used to identify them include ESA, CD44, CD24 and CD133 [69].

In a number of human tumours, overexpression of MET leads to the acquisition of a stem cell-like phenotype $[70,71]$. It is thought that overexpression of MET may facilitate the formation of CSCs from normal stem cells in the tumour microenvironment, or alternatively may encourage the de-differentiation of mature cells [36]. As a result, MET may be pivotal in the initial development of a tumour, as well as in its progression and ability to persist through cytotoxic treatment.

Hage et al. demonstrated that the MET inhibitor cabozantinib increased gemcitabine efficacy through triggering apoptosis and reducing the expression of several CSC markers, including SOX2 and CD133 in pancreatic ductal adenocarcinoma (PDAC) cells [72]. Li et al. reported that a proportion of primary PDAC CSCs express high levels of MET and have a tumourigenic phenotype in vitro and in vivo. The MET inhibitor cabozantinib and $M E T$ shRNA knockdown significantly reduced their tumourigenicity in vitro and in vivo and reduced the population of CSCs. This demonstrates the role of MET in CSCs' tumourigenicity. Moreover, combination treatment with cabozantinib and gemcitabine inhibited tumour growth and metastatic spread more than either drug alone [73]. Consistent with this, Yashiro et al. reported a synergistic antiproliferative and pro-apoptotic effect of the MET inhibitor SU11274 with SN38 in chemoresistant CSCs derived from gastric cancer cell lines (side population-enriched cancer stem cells (SP-CSCs)) [67]. It was noted that a smaller proportion of SP-CSCs than the parental cells were in the replication (S) phase of the cell cycle. Treatment with SU11274 increased the number of chemoresistant cells in Sphase. As SN38 is specifically active in S phase, this further explains the synergistic effect seen with combination treatment. SU11274 and SN38 also synergistically reduced the growth of tumour formed by the chemoresistant CSCs in mice [67].

These studies indicate that MET is a key driver of cancer cell stemness that leads to chemoresistance.

\section{MET may lead to chemoresistance through stimulating epithelial-mesenchymal transition}

The process of epithelial-mesenchymal transition (EMT) enables cells to invade surrounding tissues and metastasise, with enhanced migratory capacity, invasiveness, production of extracellular matrix components and resistance to apoptosis $[74,75]$. EMT has been shown to contribute to chemoresistance [23, 76]. Upon activation, MET is known to drive cancer cell invasion and metastasis through altering cell-cell and cell-surface adhesions and the actin cytoskeleton, leading to the acquisition of cell motility, including the formation of invadopodia [77]. MET does this by upregulating the expression of EMT markers such as vimentin and Snail and the expression or activity of matrix metalloproteinases (MMPs), which digest the surrounding stroma to promote invasion [78-80].

Culturing a SCLC cell line in the presence of HGF for 10-14 days induced EMT features, with increased Snail expression and invasiveness. The mesenchymal subpopulation of this cell line was found to secrete HGF, thus leading to an autocrine loop of MET activation. These mesenchymal cells displayed an HGF/MET-dependent EMT phenotype and acquired etoposide resistance both in vitro and in vivo xenograft experiments in nude mice. This chemotherapy resistance was reversed upon MET inhibition using crizotinib. Interestingly, an upregulation of phosphorylated MET and mesenchymal markers were observed in SCLC patient samples at relapse [37].

Two cisplatin-resistant NSCLC cell lines display MET overexpression and increased expression of $\mathrm{N}$-cadherin, vimentin, ZEB1 and Snail and reduced expression of Ecadherin compared to their isogenic parental cells [31]. MET, through the PI3K/AKT/mTOR signalling pathway was found to promote the acquisition of this EMT phenotype. Thus, overexpression of the microRNA miR-206, or knockdown of its target MET, reversed these mesenchymal features and sensitised resistant cells to cisplatin [31].

These studies suggest that MET-dependent EMT confers chemoresistance although a direct link remains to be clearly demonstrated.

\section{MET alters endothelial cells' behaviour and promotes tumour hypoxia}

During tumorigenesis cancers outgrow their blood supply and develop a necrotic, hypoxic core. Hypoxia facilitates cell survival under stress, by causing cell cycle arrest and downregulation of apoptosis, senescence and mitochondrial activity [81]. Hypoxia also induces cellular adaptations which can hinder the efficacy of chemotherapy, such as reduced cellular uptake of drugs due to increased cellular acidity and drug efflux pump expression [82], whilst some chemotherapeutic agents require oxygen in order to facilitate their cytotoxicity [24].

In response to intra-tumoural hypoxia, cancer cells express hypoxia-inducible factor- $1 \alpha$ (HIF-1 $\alpha)$, which induces the expression of the pro-angiogenic vascular endothelial growth factor (VEGF), MET and HGF. The MET/HGF signalling axis itself promotes cancer cells' 
upregulation of VEGF and downregulates the expression of anti-angiogenic proteins, such as thrombospondin 1 . In turn, VEGF or HGF can bind on VEGFR or MET, both expressed on the surface of endothelial cells, stimulating their proliferation, migration and angiogenesis [83].

Two different relationships between chemoresistance and MET activated on endothelial cells through cancer cellderived HGF have been shown.

Proliferation, survival, migration, tubulogenesis and in vivo neovascularisation of HUVEC (human umbilical vein endothelial cells) was increased significantly more with the HGF-containing conditioned medium of MDR HCC cells, compared to the conditioned medium of the isogenic parental chemosensitive cells, which contained no HGF [34]. Furthermore, siRNA knockdown of the multi-resistance gene MDR1 reduced HGF production from MDR HCC cells [34].

Huang et al. reported that the HGF-containing conditioned medium of patient-derived glioblastoma cancer cells drives endothelial cells to acquire a fibroblastic phenotype, in a process called endothelial-mesenchymal transition (Endo-MT) [40], resulting in abnormal angiogenesis, vessel leakage and hypoxia. In vivo endothelial cell-specific knockout of MET (through the generation of Tie-Cre $\mathrm{Met}^{\mathrm{fl} / \mathrm{fl}}$ mice) led to normalised vasculature, reduced intratumoural hypoxia, slowed glioblastoma growth and importantly, sensitised glioblastoma tumours to temozolomide treatment, prolonging mouse survival [40].

These two studies indicate that MET activation on endothelial cells by HGF secreted by cancer cells can facilitate chemoresistance in two different ways. Drug resistance can trigger an increased production of HGF by cancer cells, leading to tumour angiogenesis. Alternatively, HGF secretion by cancer cells can trigger chemoresistance through altering angiogenesis and triggering hypoxia.

\section{Clinical uses of MET inhibitors in chemoresistance}

As discussed above, a number of clinical trials have evaluated MET inhibitors as a monotherapy against other targeted therapies or standard of care chemotherapy regimens (see Table 1). Crizotinib and cabozantinib were approved based on superiority to chemotherapy and the mTOR inhibitor everolimus, respectively [84, 85]. These two drugs are multi-kinase inhibitors, however, so it is difficult to draw conclusions about whether the positive results were associated with their MET activity. Capmatinib is a selective MET inhibitor that has been granted accelerated FDA approval for patients with NSCLC whose tumours harbour MET exon 14 mutation [16]. None of these trials directly addressed the reversal of chemotherapy resistance with MET inhibition.
Following strong preclinical evidence for the additive or synergistic efficacy of MET inhibitors in combination with chemotherapy, a number of clinical trials assessing combination therapy have been conducted in solid cancers. These trials are outlined in Table 4. Trial data is mature in gastric, prostate and colorectal cancers. Unfortunately, no trial to date has demonstrated a significant improvement in median overall survival (mOS) with the addition of MET-targeted therapy to chemotherapy. The phase II trial investigating the addition of the anti-HGF antibody rilotumumab to ECX (epirubicin, cisplatin and capecitabine) chemotherapy in gastric adenocarcinoma demonstrated a modest improvement in progression-free survival (PFS, 5.7 vs 4.2 months) and objective response rate (ORR, 39\% vs 21\%) [86] compared to placebo plus ECX. However, the phase III trial of this combination had to be terminated early due to fatal side effects (including febrile neutropenia) in the rilotumumab arm [87]. In the phase II study, the MET positive subgroup of patients, as determined by IHC, had a prolonged mOS in the rilotumumab arm compared to the placebo arm [86]. In other trials, however, no correlation between MET expression and response to MET-targeted therapy was observed.

\section{Optimising preclinical research and future directions for the clinical utility of MET inhibitors in chemoresistant disease}

The modest clinical benefit of MET/HGF inhibitors in combination with chemotherapy in clinical trials necessitates review of why the preclinical evidence for these compounds is not translating into clinical practice.

\section{The use of appropriate modelling systems}

In this review we have outlined the cell-based models used to demonstrate the mechanisms of MET-driven chemoresistance. It is important to recognise the limitations of using cell lines in research. For example, Domcke et al. recently highlighted that a number of the more commonly used cell lines in preclinical ovarian cancer research do not accurately represent human disease [88]. A number of studies that we have discussed used cell lines of tumour types that are known to be chemoresistant, such as glioblastoma, whilst other groups created novel chemotherapy resistant cell lines by culturing cells in increasing doses of cytotoxic chemotherapy. Isogenic chemosensitive and resistant cell pairs enabled a direct comparison between chemoresistant and chemosensitive cells lines, and highlighted aberration of the MET/HGF pathway as a common feature of chemoresistant cell lines (see Table 3). However, one possible limitation to such otherwise powerful models is that they may not 
Table 4 A summary of the clinical trial results of MET inhibitors alongside chemotherapy versus chemotherapy alone.

\begin{tabular}{|c|c|c|c|c|c|}
\hline Cancer & Trial arms, Reference, Phase, N & ORS, PFS, mOS & MET IHC scoring method & Other biomarkers & Outcome \\
\hline \multirow{4}{*}{ Gastric } & $\begin{array}{l}\text { Rilotumumab + ECX vs. placebo + } \\
\text { ECX, NCT00719550, II, } 121\end{array}$ & \begin{tabular}{|c|}
39 vs. $21^{\mathrm{b}}$ \\
5.7 vs. $4.2(p=0 \cdot 016)$ \\
10.6 vs. $8.9(p=0.109)$
\end{tabular} & $\begin{array}{c}\text { MET positive }=\geq 25 \text { or } 50 \% \text { with } \\
\text { membrane staining on tumour cells at } \\
\text { any intensity }\end{array}$ & \begin{tabular}{|c|} 
MET gene copy \\
number, HER2 \\
expression, circulating \\
HGF, soluble MET \\
\end{tabular} & $\begin{array}{l}\text { Greater activity } \\
\text { No safety signals }\end{array}$ \\
\hline & $\begin{array}{c}\text { Onartuzumab + mFOLFOX6* vs. } \\
\text { placebo + mFOLFOX6 as } 1 \text { st line } \\
\text { treatment in HER2- gastric cancer } \\
\text { NCT01590719, II, } 123 \\
\end{array}$ & $\begin{array}{c}60.5 \text { vs. } 57.1^{\mathrm{b}} \\
6.77 \text { vs. } 6.97(p=0.71) \\
10.61 \text { vs. } 11.27 \\
(p=0.83) \\
\end{array}$ & $\begin{array}{l}\text { MET positive }=\geq 50 \% \text { of tumour cells } \\
\text { with moderate or strong intensity }\end{array}$ & $\begin{array}{c}\text { Baseline tumour HGF } \\
\text { levels }\end{array}$ & $\begin{array}{l}\text { No efficacy improvement in an } \\
\text { unselected population or in a } \\
\text { MET IHC-positive population. }\end{array}$ \\
\hline & $\begin{array}{c}\text { Rilotumumab +ECX vs. placebo + ECX } \\
\text { as } 1^{\text {st }} \text { line treatment in MET+ gastric } \\
\text { cancer, NCT01697072, III, } 609\end{array}$ & \begin{tabular}{|c|}
29.8 vs. $44.6(p=$ \\
$0.0005)$ \\
5.6 vs. $6.0(p=0.013)$ \\
8.8 vs. $10.7(p=0.03)$ \\
\end{tabular} & $\mid \begin{array}{c}\text { MET positive }=\geq 25 \% \text { of tumour cells } \\
\text { with membrane staining at an intensity } \\
\text { of } 1+\text { or greater }^{\text {a }}\end{array}$ & $\begin{array}{c}\text { MET gene } \\
\text { amplification, baseline } \\
\text { serum HGF levels }\end{array}$ & $\begin{array}{l}\text { Terminated early due to more } \\
\text { deaths in rilotumumab group }\end{array}$ \\
\hline & $\begin{array}{c}\text { Onartuzumab + mFOLFOX6* vs. } \\
\text { placebo + mFOLFOX6 as } 1^{\text {st line }} \\
\text { treatment in MET+, HER2- gastric } \\
\text { cancer, NCT01662869, 3, 562 }\end{array}$ & $\begin{array}{c}6.1 \text { vs. } 40.6(p=0.25) \\
6.8 \text { vs. } 6.7(p=0.43) \\
11 \text { vs. } 11.3(p=0.24)\end{array}$ & $\begin{array}{c}\text { MET positive }=\geq 50 \% \text { of tumour } \\
\text { membrane staining on tumour cells at } \\
\text { any intensity }\end{array}$ & HER2 expression & No significant improvement \\
\hline Prostate & \begin{tabular}{|c|} 
Rilotumumab + mitoxantrone + \\
prednisone vs. placebo + mitoxantrone \\
+ prednisone as $2^{\text {nd }}$ line therapy in \\
CRPC who had received previous \\
taxane chemotherapy \\
NCT00770848, 2,144 \\
\end{tabular} & \begin{tabular}{|}
56 vs. $57^{\mathrm{b}}$ \\
3.0 vs. $2.9(p=0.94)$ \\
12.2 vs. $11.1(p=0.673)$ \\
\end{tabular} & $\begin{array}{l}\text { MET High subgroup had }>50 \% \text { of } \\
\text { tumour cells with } \geq 1+\text { staining; } \\
\text { MET } \\
\text { tumow } \text { subgroup had } \leq 50 \% \text { of } \\
\text { tum cells with } \geq 1+\text { staining }\end{array}$ & $\begin{array}{l}\text { Plasma levels of total } \\
\text { HGF and soluble MET }\end{array}$ & $\begin{array}{l}\text { No efficacy improvements } \\
\text { Manageable toxicities }\end{array}$ \\
\hline \multirow{2}{*}{$\mathrm{CRC}$} & $\begin{array}{c}\text { Onartuzumab + FOLFOX/bevacizumab } \\
\text { vs. placebo + FOLFOX/bevacizumab } \\
\text { in the treatment of metastatic CRC } \\
\text { NCT01418222, 2, } 194\end{array}$ & $\begin{array}{c}57.3 \text { vs. } 57.7(p=1.00) \\
11.0 \text { vs. } 10.3(p=0.12) \\
22.2 \text { vs. not reached } \\
(p=0.85)\end{array}$ & $\begin{array}{c}\text { CONFIRM }^{\mathrm{TM}} \text { anti-total MET (SP44) } \\
\text { antibody. MET positive= scores of } \\
2+/ 3+(\geq 50 \% \text { moderate or strong } \\
\text { intensity staining in tumour cells) } \\
\text { MET negative }=\text { scores of } 0 / 1+\mathrm{a}\end{array}$ & $\begin{array}{l}\text { HGF expression in } \\
\text { tissue and plasma } \\
\text { samples }\end{array}$ & $\begin{array}{l}\text { No efficacy improvement. } \\
\text { MET expression by IHC was not } \\
\text { a predictive biomarker }\end{array}$ \\
\hline & \begin{tabular}{|c|} 
Tivantinib + cetuximab and irinotecan \\
vs. placebo + cetuximab and irinotecan \\
in the treatment of advanced CRC \\
NCT01075048, 2, 117
\end{tabular} & \begin{tabular}{|c|}
45 vs. $33(p=0.14)$ \\
8.3 vs. 7.3 months \\
$(p=0.38)$ \\
19.8 vs. $16.9(p=0.15)$
\end{tabular} & \begin{tabular}{|c|} 
CONFIRM $^{\mathrm{TM}}$ anti-total MET (SP44) \\
antibody, adjudicated by three \\
pathologists. MET-High samples $=\geq 2+$ \\
score in $\geq 50 \%$ of tumour tissue
\end{tabular} & No & $\begin{array}{l}\text { Not significant improvement } \\
\text { Promising results in MET-High } \\
\text { subgroup: further study in selected } \\
\text { mCRC patients warranted. }\end{array}$ \\
\hline
\end{tabular}

This table summarises the results that are currently available for completed Phase II/III clinical trials using MET/HGF inhibitors alongside chemotherapy.

$N$ sample size, ORS objective response rate (\%), PFS progression free survival, $m O S$ median overall survival, ECX epirubicin, cisplatin and capecitabine, $I H C$ immunohistochemistry, $C R P C$ castration-resistant prostate cancer, $C R C$ colorectal cancer, $m F O L F O X 6$ fluorouracil, leucovorin and oxaliplatin.

The red box indicates that there was a correlation between MET expression and the study outcome.

${ }^{a} 0$ (unstained), $1+$ (weak staining), $2+$ (moderate staining), and 3+ (strong staining).

${ }^{\mathrm{b}} p$-values not reported.

accurately reflect the chemoresistance seen in human disease. Therefore, results obtained in isogenic models would highly benefit from validation in patient-derived primary cells and human samples in future studies.

2D models have formed the basis of many scientific discoveries, but the use of 2D models can result in cellular behaviour that deviates dramatically from the in vivo response. In addition, many important characteristics of cancer cells cannot be appropriately modelled in 2D cultures, including exposure to growth factors, cellular polarity and cellular adhesion $[89,90]$. The majority of preclinical studies investigating the efficacy of MET inhibitors in vitro use 2D models, such as clonogenic assays and cell viability assays. Indeed, a review of the preclinical evidence for MET inhibitors in pancreatic cancer acknowledged that none of the preclinical cancer models had considered the role of the stroma in MET/HGF pathway signalling [91]. In pancreatic cancer, the predominant source of HGF is from pancreatic stellate cells (PSCs), but many of the in vitro studies only included endothelial cells and vascular smooth muscle cells to represent the stroma [92].
In recent years, a number of novel 3D cell culture models have been developed to better replicate the dimensionality of the extracellular matrix. As a result, 3D models have proven to be more capable of inducing in vivo-like cell fates than their 2D counterparts. Expanding the use of 3D models in MET-targeted preclinical research is therefore likely to provide data that will better inform in vivo and clinical testing.

A major proportion of in vivo research on MET inhibitors has been performed in immunosuppressed mice to allow for xenotransplantation of human cells without rejection. There is increasing evidence that the tumour microenvironment (TME) that comprises cancer cells, tumour stroma, blood vessels and immune infiltrate, promotes cancer progression and alters tumour sensitivity to therapy. Until now the interplay between MET signalling and the immune system has been largely uncharacterised. One key study has demonstrated that MET/HGF signalling is involved in mediating the recruitment of neutrophils into the TME, and as such is thought to play a role in regulating tumour immunity to some therapies [93]. Finiguerra et al. 
similarly showed that MET is required for neutrophil chemoattraction and cytotoxicity in response to HGF; however, they also demonstrated that the effect of MET tyrosine kinase inhibitors was tempered by a pro-tumoural effect of MET blockade in neutrophils [94]. In light of this, the use of immunocompetent mice models, such as genetically engineered (GEM) or syngeneically transplanted models would enhance the ability to effectively represent MET-mediated cellular behaviours. This would provide a more accurate depiction of the action of MET inhibitors in vivo, and subsequently their likely clinical benefit.

\section{Improved biomarkers for tumour/patient selection}

Accurate patient selection for MET-targeted therapy is vital. A number of studies have determined that increased expression of MET is linked with poor clinical outcomes. For example, MET overexpression has been associated with more invasive advanced tumours in glioblastoma [95] and oesophageal squamous cell carcinoma [96], a significantly increased risk of tumour recurrence in colorectal cancer [97], and reduced survival in glioblastoma [58, 95], colorectal cancer [97] and breast cancer [98, 99]. Clinicopathologic associations have also indicated that MET overexpression is associated with resistance to chemotherapy in breast cancer [98, 99] and oesophageal squamous cell carcinoma [96].

The modest effect of MET-targeted treatments seen in clinical trials to date may be due to inadequate patient stratification. Patient stratification has unfortunately been hindered by the lack of a reliable biomarker of MET activity. As seen in Table 4, all of the clinical trials testing MET/HGF-directed therapy alongside chemotherapy assessed MET expression using immunohistochemical (IHC) staining of tumour samples. Thus, tumours were stratified by total MET cell surface expression. With the exception of the phase II study of the anti-HGF antibody rilotumumab in gastric cancer, all trials demonstrated no relationship between MET expression and response to MET inhibitors [100].

The use of total MET as a surrogate marker for pathway activation is questionable for the following reasons:

(i) Levels of expression do not necessarily correlate with levels of activity. For example, MET may still be highly activated in tumours with low expression if the level of HGF in the TME is high. Also, oncogenic mutations that trigger MET activation do not necessarily trigger MET overexpression [101].

(ii) As discussed above, total MET IHC is usually scored on staining within the plasma membrane. MET has been shown to remain active post-endocytosis and furthermore to require endocytosis to sustain its activation and/or downstream signalling [3-5]. Therefore, new scoring methods that take into account MET staining in the cytoplasm, in addition to the plasma membrane, will enhance patient selection and subsequent outcomes.

(iii) Importantly, in all preclinical and clinical studies to date, different antibodies, molecular tests and evaluation criteria have been used, limiting the validity of the outcomes. Unlike other molecular markers, such as the oestrogen receptor and HER2, robust comparable testing and evaluation criteria for MET have not yet been developed.

Many trials performed exploratory analyses of other potential biomarkers such as serum HGF level, tumour HGF level, MET gene copy number (amplification) and soluble MET concentrations (see Table 4). Unfortunately, no clinically meaningful correlation was seen between any of these biomarkers and treatment response. Consistent with this, one study reported that serum MET levels were not indicative of MET present within tumours [102]. This relationship has also been explored using cell line panels and a lack of correlation between mRNA expression, protein expression and activation of MET was seen [103].

The only indicators proven to correspond to pathway activity are MET phosphorylation (phospho-MET) and MET exon 14 deletions [104], but MET mutations are rare in general cancer populations. Phospho-MET has not been used as a selection criterion for clinical trials so far [103]. Unfortunately, there are significant limitations with phospho-MET antibodies, as they have poor sensitivity and specificity [17, 37]. In addition, there are conflicting reports about the correlation between MET expression and phosphorylated MET on patient samples. One study has shown no link between the staining patterns [105], whereas another noted that MET phosphorylation is associated with 'high' MET scores. Copin et al. demonstrated that in NSCLC tumours phosphorylated MET was restricted to $<20 \%$ of the tumour cells and mostly at the invasive front [102]. As a consequence, and also for the reasons stated above, the levels of activity do not necessarily correlate with level of expression.

Therefore, until a reliable biomarker of MET activity is elucidated, the method of patient stratification in trials will continue to be a matter for debate. It is possible that once biomarkers used for selection of patients for targeted therapies against MET have been adequately established, they might also be used for as an adjunct for identification of resistance to chemotherapy.

\section{Conclusion}

In conclusion, chemotherapy resistance remains one of the fundamental barriers to effectively treating cancer. MET provides a promising target to reverse chemoresistance, but to date there has been poor translation of preclinical data to 
positive clinical trials outcomes. By further exploiting the mechanisms of MET-mediated chemoresistance and optimising patient stratification, there is hope for improved outcomes in targeting MET in patients with chemotherapy resistant cancers.

\section{Compliance with ethical standards}

Conflict of interest The authors declare that they have no conflict of interest.

Publisher's note Springer Nature remains neutral with regard to jurisdictional claims in published maps and institutional affiliations.

Open Access This article is licensed under a Creative Commons Attribution 4.0 International License, which permits use, sharing, adaptation, distribution and reproduction in any medium or format, as long as you give appropriate credit to the original author(s) and the source, provide a link to the Creative Commons license, and indicate if changes were made. The images or other third party material in this article are included in the article's Creative Commons license, unless indicated otherwise in a credit line to the material. If material is not included in the article's Creative Commons license and your intended use is not permitted by statutory regulation or exceeds the permitted use, you will need to obtain permission directly from the copyright holder. To view a copy of this license, visit http://creativecommons. org/licenses/by/4.0/

\section{References}

1. Organ SL, Tsao MS. An overview of the c-MET signaling pathway. Ther Adv Med Oncol. 2011;3:S7-19.

2. Comoglio PM, Giordano S, Trusolino L. Drug development of MET inhibitors: targeting oncogene addiction and expedience. Nat Rev Drug Discov. 2008;7:504-16.

3. Kermorgant S, Parker PJ. Receptor trafficking controls weak signal delivery: a strategy used by c-Met for STAT3 nuclear accumulation. J Cell Biol. 2008;182:855-63.

4. Ménard L, Parker PJ, Kermorgant S. Receptor tyrosine kinase cMet controls the cytoskeleton from different endosomes via different pathways. Nat Commun. 2014;5. https://doi.org/10. 1038/ncomms4907.

5. Barrow-McGee R, Kermorgant S. Met endosomal signalling: in the right place, at the right time. Int $\mathrm{J}$ Biochem Cell Biol. 2014;49:69-74

6. Kong-Beltran M, Seshagiri S, Zha J, Zhu W, Bhawe K, Mendoza $\mathrm{N}$, et al. Somatic mutations lead to an oncogenic deletion of Met in lung cancer. Cancer Res. 2006;66:283-9.

7. Corso S, Comoglio PM, Giordano S. Cancer therapy: can the challenge be MET? Trends Mol Med. 2005;11:284-92.

8. Matsumoto K, Nakamura T. Roles of HGF as a pleiotropic factor in organ regeneration. EXS. 1993;65:225-49.

9. Tovar EA, Graveel CR. MET in human cancer: germline and somatic mutations. Ann Transl Med. 2017;5:205.

10. Schmidt L, Duh FM, Chen F, Kishida T, Glenn G, Choyke P, et al. Germline and somatic mutations in the tyrosine kinase domain of the MET proto-oncogene in papillary renal carcinomas. Nat Genet. 1997;16:68-73.

11. Neklason DW, Done MW, Sargent NR, Schwartz AG, AntonCulver $\mathrm{H}$, Griffin CA, et al. Activating mutation in MET oncogene in familial colorectal cancer. BMC Cancer. 2011;11:424.
12. Park WS, Dong SM, Kim SY, Na EY, Shin MS, Pi JH, et al. Somatic mutations in the kinase domain of the met/hepatocyte growth factor receptor gene in childhood hepatocellular carcinomas. Cancer Res. 1999;59:307-10.

13. Siegfried JM, Weissfeld LA, Luketich JD, Weyant RJ, Gubish CT, Landreneau RJ. The clinical significance of hepatocyte growth factor for non-small cell lung cancer. Ann Thorac Surg. 1998;66:1915-8.

14. Elliott BE, Hung WL, Boag AH, Tuck AB. The role of hepatocyte growth factor (scatter factor) in epithelial-mesenchymal transition and breast cancer. Can J Physiol Pharm. 2002;80:91-102.

15. Lutterbach B, Zeng Q, Davis LJ, Hatch H, Hang G, Kohl NE, et al. Lung cancer cell lines harboring Met gene amplification are dependent on Met for growth and survival. Cancer Res. 2007;67:2081-8.

16. Wolf J, Seto T, Han J-Y, Reguart N, Garon EB, Groen HJM, et al. Capmatinib (INC280) in MET $\Delta$ ex14 -mutated advanced non-small cell lung cancer (NSCLC): efficacy data from the phase II GEOMETRY mono-1 study. J Clin Oncol. 2019;37:9004-9004.

17. Koch JP, Aebersold DM, Zimmer Y, Medová M. MET targeting: time for a rematch. Oncogene. 2020;39:2845-62.

18. Cattley RC, Radinsky RR. Cancer therapeutics: understanding the mechanism of action. Toxicol Pathol. 2004;32:116-21.

19. Zhou J, Kang Y, Chen L, Wang H, Liu J, Zeng S, et al. The drug-resistance mechanisms of five platinum-based antitumor agents. Front. Pharmacol. 2020;11. https://doi.org/10.3389/fphar. 2020.00343.

20. Vaidyanathan A, Sawers L, Gannon AL, Chakravarty P, Scott AL, Bray SE, et al. ABCB1 (MDR1) induction defines a common resistance mechanism in paclitaxel- and olaparib-resistant ovarian cancer cells. Br J Cancer. 2016;115:431-41.

21. Desbats MA, Giacomini I, Prayer-Galetti T, Montopoli M. Metabolic plasticity in chemotherapy resistance. Front. Oncol. 2020;10. https://doi.org/10.3389/fonc.2020.00281.

22. Nunes T, Hamdan D, Leboeuf C, El Bouchtaoui M, Gapihan G, Nguyen TT, et al. Targeting cancer stem cells to overcome chemoresistance. Int J Mol Sci. 2018;19. https://doi.org/10.3390/ ijms 19124036.

23. Lu W, Kang Y. Epithelial-mesenchymal plasticity in cancer progression and metastasis. Dev Cell. 2019;49:361-74.

24. Cosse J-P, Michiels C. Tumour hypoxia affects the responsiveness of cancer cells to chemotherapy and promotes cancer progression. Anticancer Agents Med Chem. 2012;8:790-7.

25. Caenepeel S, Cooke K, Wadsworth S, Huang G, Robert L, Moreno BH, et al. MAPK pathway inhibition induces MET and GAB1 levels, priming BRAF mutant melanoma for rescue by hepatocyte growth factor. Oncotarget. 2017;8:17795-809.

26. Engelman JA, Zejnullahu K, Mitsudomi T, Song Y, Hyland C, Joon OP, et al. MET amplification leads to gefitinib resistance in lung cancer by activating ERBB3 signaling. Science. 2007;316:1039-43.

27. Ko B, He T, Gadgeel S, Halmos B. MET/HGF pathway activation as a paradigm of resistance to targeted therapies. Ann. Transl. Med. 2017;5:1-16.

28. Ozasa H, Oguri T, Maeno K, Takakuwa O, Kunii E, Yagi Y, et al. Significance of c-MET overexpression in cytotoxic anticancer drug-resistant small-cell lung cancer cells. Cancer Sci. 2014;105:1032-9.

29. Moschetta M, Basile A, Ferrucci A, Frassanito MA, Rao L, Ria $\mathrm{R}$, et al. Novel targeting of phospho-cMET overcomes drug resistance and induces antitumor activity in multiple myeloma. Clin Cancer Res. 2013;19:4371-82.

30. Li E, Hu Z, Sun Y, Zhou Q, Yang B, Zhang Z, et al. Small molecule inhibitor of c-Met (PHA665752) suppresses the growth of ovarian cancer cells and reverses cisplatin resistance. Tumor Biol. 2016. https://doi.org/10.1007/s13277-015-4318-x. 
31. Chen Q-Y, Jiao D-M, Wang J, Hu H, Tang X, Chen J, et al. miR206 regulates cisplatin resistance and EMT in human lung adenocarcinoma cells partly by targeting MET. Oncotarget. 2016;7:24510-26.

32. Jung K-A, Choi B-H, Kwak M-K. The c-MET/PI3K signaling is associated with cancer resistance to doxorubicin and photodynamic therapy by elevating BCRP/ABCG2 expressions. Mol Pharm Mol Pharm. 2015;87:465-76.

33. Hung T-H, Li Y-H, Tseng C-P, Lan Y-W, Hsu S-C, Chen Y-H, et al. Knockdown of c-MET induced apoptosis in ABCB1overexpressed multidrug-resistance cancer cell lines. Cancer Gene Ther. 2015;22:262-70.

34. Lasagna N, Fantappiè O, Solazzo M, Morbidelli L, Marchetti S, Cipriani G, et al. Hepatocyte growth factor and inducible nitric oxide synthase are involved in multidrug resistance-induced angiogenesis in hepatocellular carcinoma cell lines. Cancer Res. 2006;66:2673-82.

35. Tang X, Yan L, Zhu L, Jiao D, Chen J, Chen Q. Salvianolic acid A reverses cisplatin resistance in lung cancer A549 cells by targeting c-met and attenuating Akt/mTOR pathway. J Pharm Sci. 2017;135:1-7.

36. Avan A, Quint K, Nicolini F, Funel N, Frampton AE, Maftouh $\mathrm{M}$, et al. Enhancement of the antiproliferative activity of gemcitabine by modulation of c-Met pathway in pancreatic cancer. Curr. Pharm. Des. 2013;19:940-50.

37. Canadas I, Rojo F, Taus A, Arpi O, Uria MA, Pijuan L, et al. Targeting epithelial-to-mesenchymal transition with met inhibitors reverts chemoresistance in small cell lung cancer. Clin Cancer Res. 2014;20:938-50.

38. Deying W, Feng G, Shumei L, Hui Z, Ming L, Hongqing W. CAFderived HGF promotes cell proliferation and drug resistance by upregulating the c-Met/PI3K/Akt and GRP78 signalling in ovarian cancer cells. Biosci Rep. 2017;37: BSR20160470.

39. Bowers DC, Fan S, Walter KA, Abounader R, Williams JA, Rosen EM, et al. Scatter factor/hepatocyte growth factor protects against cytotoxic death in human glioblastoma via phosphatidylinositol 3-Kinase-and AKT-dependent pathways 1. Cancer Res. 2000;60:4277-83.

40. Huang M, Liu T, Ma P, Mitteer RA, Zhang Z, Kim HJ, et al. cMet-mediated endothelial plasticity drives aberrant vascularization and chemoresistance in glioblastoma. J Clin Invest. 2016;126:1801-14.

41. Hervieu A, Kermorgant S. The role of PI3K in Met driven cancer: a recap. Front Mol Biosci. 2018;5:86.

42. Trusolino L, Bertotti A, Comoglio PM. MET signalling: principles and functions in development, organ regeneration and cancer. Nat Rev Mol Cell Biol. 2010;11:834-48.

43. del Peso L, González-García M, Page C, Herrera R, Nuñez G. Interleukin-3-induced phosphorylation of BAD through the protein kinase Akt. Science. 1997;278:687-9.

44. Fan S, Wang JA, Yuan RQ, Rockwell S, Andres J, Zlatapolskiy A, et al. Scatter factor protects epithelial and carcinoma cells against apoptosis induced by DNA-damaging agents. Oncogene. 1998;17:131-41.

45. Wang K, Zhuang Y, Liu C, Li Y. Inhibition of c-Met activation sensitizes osteosarcoma cells to cisplatin via suppression of the PI3K-Akt signaling. Arch Biochem Biophys. 2012;526:38-43.

46. Chen JT, Huang CY, Chiang YY, Chen WH, Chiou SH, Chen $\mathrm{CY}$, et al. HGF increases cisplatin resistance via down-regulation of AIF in lung cancer cells. Am J Respir Cell Mol Biol. 2008;38:559-65.

47. Fan S, Ma YX, Wang JA, Yuan RQ, Meng Q, Cao Y, et al. The cytokine hepatocyte growth factor/scatter factor inhibits apoptosis and enhances DNA repair by a common mechanism involving signaling through phosphatidyl inositol 3' kinase. Oncogene. 2000;19:2212-23.
48. Tang MKS, Zhou HY, Yam JWP, Wong AST. c-Met overexpression contributes to the acquired apoptotic resistance of nonadherent ovarian cancer cells through a cross talk mediated by phosphatidylinositol 3-kinase and extracellular signalregulated kinase 1/2 1,2. Neoplasia. 2010;12:128-38.

49. Candé C, Cohen I, Daugas E, Ravagnan L, Larochette N, Zamzami N, et al. Apoptosis-inducing factor (AIF): a novel caspase-independent death effector released from mitochondria. Biochimie. 2002;84:215-22.

50. Fu Y, Li J, Lee AS. GRP78/BiP inhibits endoplasmic reticulum BIK and protects human breast cancer cells against estrogen starvation-induced apoptosis. Cancer Res. 2007;67:3734-40.

51. Zhou H, Zhang Y, Fu Y, Chan L, Lee AS. Novel mechanism of anti-apoptotic function of $78-\mathrm{kDa}$ glucose-regulated protein (GRP78). J Biol Chem. 2011;286:25687-96.

52. Meng Q, Mason JM, Porti D, Goldberg ID, Rosen EM, Fan S. Hepatocyte growth factor decreases sensitivity to chemotherapeutic agents and stimulates cell adhesion, invasion, and migration. Biochem Biophys Res Commun. 2000;274:772-9.

53. Marchion DC, Bicaku E, Xiong Y, Zgheib NB, Al Sawah E, Stickles XB, et al. A novel c-Met inhibitor, MK8033, synergizes with carboplatin plus paclitaxel to inhibit ovarian cancer cell growth. Oncol Rep. 2013;29:2011-8.

54. Wang J, Cheng JX. c-Met inhibition enhances chemosensitivity of human ovarian cancer cells. Clin Exp Pharm Physiol. 2017;44:79-87.

55. Huang XX, Xie FF, Hou LJ, Chen XX, Ou RY, Yu JT, et al. Crizotinib synergizes with cisplatin in preclinical models of ovarian cancer. Am J Transl Res. 2017;9:1667-79.

56. Medová M, Aebersold DM, Blank-Liss W, Streit B, Medo M, Aebi $\mathrm{S}$, et al. MET inhibition results in DNA breaks and synergistically sensitizes tumor cells to DNA-damaging agents potentially by breaching a damage-induced checkpoint arrest. Genes Cancer. 2010;1:1053-62.

57. Rucki AA, Xiao Q, Muth S, Chen J, Che X, Kleponis J, et al. Dual inhibition of Hedgehog and c-Met pathways for pancreatic cancer treatment. Mol Cancer Ther. 2017;16:2399-409.

58. Li MY, Yang P, Liu YW, Zhang CB, Wang KY, Wang YY, et al. Low c-Met expression levels are prognostic for and predict the benefits of temozolomide chemotherapy in malignant gliomas. Sci Rep. 2016;6:1-10.

59. Chu SH, Ma Y-B, Feng DF, Zhang H, Qiu JHZZ. c-Met antisense oligodeoxynucleotides increase sensitivity of human glioma cells to paclitaxel. Oncol Rep. 2010;24:189-94.

60. Que W, Chen J. Knockdown of c-Met inhibits cell proliferation and invasion and increases chemosensitivity to doxorubicin in human multiple myeloma U266 cells in vitro. Mol Med Rep. 2011;4:343-9.

61. Zhang Q, Zhang H, Ning T, Liu D, Deng T, Liu R, et al. Exosome-delivered c-Met siRNA could reverse chemoresistance to cisplatin in gastric cancer. Int J Nanomed. 2020;15:2323-35.

62. O'Connor MJ. Targeting the DNA damage response in cancer. Mol Cell. 2015;60:547-60.

63. Blackford AN, Jackson SP. ATM, ATR, and DNA-PK: the trinity at the heart of the DNA damage response. Mol Cell. 2017;66:801-17.

64. Stacy AE, Jansson PJ, Richardson DR. Molecular pharmacology of ABCG2 and its role in chemoresistance. Mol Pharmacol. 2013;84:655-69.

65. Litman T, Brangi M, Hudson E, Fetsch P, Abati A, Ross DD, et al. The multidrug-resistant phenotype associated with overexpression of the new ABC half-transporter, MXR (ABCG2). J Cell Sci. 2000;113:2011-21.

66. Sun S, Cai J, Yang Q, Zhu Y, Zhao S, Wang Z. Prognostic value and implication for chemotherapy treatment of ABCB1 in epithelial ovarian cancer: a meta-analysis. PLoS One. 2016;11. https://doi.org/10.1371/journal.pone.0166058. 
67. Yashiro M, Nishii T, Hasegawa T, Matsuzaki T, Morisaki T, Fukuoka T, et al. A c-Met inhibitor increases the chemosensitivity of cancer stem cells to the irinotecan in gastric carcinoma. Br J Cancer. 2013;109:2619-28.

68. Beck B, Blanpain C. Unravelling cancer stem cell potential. Nat Rev Cancer. 2013;13:727-38.

69. Yu Z, Pestell TG, Lisanti MP, Pestell RG. Cancer stem cells. Int J Biochem Cell Biol. 2012;44:2144-51.

70. Delitto D, Vertes-George E, Hughes SJ, Behrns KE, Trevino JG. c-Met signaling in the development of tumorigenesis and chemoresistance: potential applications in pancreatic cancer. World $\mathbf{J}$ Gastroenterol. 2014;20:8458-70.

71. van Leenders GJLH, Sookhlall R, Teubel WJ, de Ridder CMA, Reneman S, Sacchetti A, et al. Activation of c-MET induces a stem-like phenotype in human prostate cancer. PLoS One. 2011;6:e26753.

72. Hage C, Rausch V, Giese N, Giese T, Schönsiegel F, Labsch S, et al. The novel c-Met inhibitor cabozantinib overcomes gemcitabine resistance and stem cell signaling in pancreatic cancer. Cell Death Dis. 2013; 627:1-10.

73. Li C, Wu J-J, Hynes M, Dosch J, Sarkar B, Welling TH, et al. cMet is a marker of pancreatic cancer stem cells and therapeutic target. Gastroenterology. 2011;141:2218-27.e5.

74. Kalluri R, Neilson EG. Epithelial-mesenchymal transition and its implications for fibrosis. J Clin Invest. 2003;112:1776-84.

75. Yang J, Antin P, Berx G, Blanpain C, Brabletz T, Bronner M, et al. Guidelines and definitions for research on epithelial-mesenchymal transition. Nat Rev Mol Cell Biol. 2020;21:341-52.

76. Wang J, Wei Q, Wang X, Tang S, Liu H, Zhang F, et al. Transition to resistance: an unexpected role of the EMT in cancer chemoresistance. Genes Dis. 2016;3:3-6.

77. Rajadurai CV, Havrylov S, Zaoui K, Vaillancourt R, Stuible M, Naujokas $\mathbf{M}$, et al. Met receptor tyrosine kinase signals through a cortactin-Gab1 scaffold complex, to mediate invadopodia. J Cell Sci. 2012;125:2940-53.

78. Trusolino L, Comoglio PM. Scatter-factor and semaphorin receptors: cell signalling for invasive growth. Nat Rev Cancer. 2002;2:289-300.

79. Kermorgant S, Aparicio T, Dessirier V, Lewin MJM, Lehy T. Hepatocyte growth factor induces colonic cancer cell invasiveness via enhanced motility and protease overproduction. Evidence for P13 kinase and PKC involvement. Carcinogenesis. 2001;22:1035-42.

80. Beviglia L, Kramer RH. HGF induces FAK activation and integrin-mediated adhesion in MTLn3 breast carcinoma cells. Int J Cancer. 1999;83:640-9.

81. Rohwer N, Cramer T. Hypoxia-mediated drug resistance: novel insights on the functional interaction of HIFs and cell death pathways. Drug Resist Updat. 2011;14:191-201.

82. Abraham J, Salama NN, Azab AK. The role of P-glycoprotein in drug resistance in multiple myeloma. Leuk Lymphoma. 2015;56:26-33.

83. Gherardi E, Birchmeier W, Birchmeier C, Vande WoudeG. Targeting MET in cancer: rationale and progress. Nat Rev Cancer. 2012;12:89-103.

84. Solomon BJ, Mok T, Kim D-W, Wu Y-L, Nakagawa K, Mekhail $\mathrm{T}$, et al. First-line crizotinib versus chemotherapy in $A L K$ -positive lung cancer. N. Engl J Med. 2014;371:2167-77.

85. Choueiri TK, Escudier B, Powles T, Tannir NM, Mainwaring PN, Rini BI, et al. Cabozantinib versus everolimus in advanced renal cell carcinoma (METEOR): final results from a randomised, open-label, phase 3 trial. Lancet Oncol. 2016;17:917-27.

86. Iveson T, Donehower RC, Davidenko I, Tjulandin S, Deptala A, Harrison M, et al. Rilotumumab in combination with epirubicin, cisplatin, and capecitabine as first-line treatment for gastric or oesophagogastric junction adenocarcinoma: an open-label, dose de-escalation phase $1 \mathrm{~b}$ study and a double-blind, randomised phase 2 study. Lancet Oncol. 2014;15:1007-18.

87. Ilson DH, Al-Batran S-E, Tjulandin S, Sidhu R, Cunningham D, Tang $\mathrm{R}$, et al. Rilotumumab plus epirubicin, cisplatin, and capecitabine as first-line therapy in advanced MET-positive gastric or gastro-oesophageal junction cancer (RILOMET-1): a randomised, double-blind, placebo-controlled, phase 3 trial. Lancet Oncol. 2017;18:1467-82.

88. Domcke S, Sinha R, Levine DA, Sander C, Schultz N Evaluating cell lines as tumour models by comparison of genomic profiles. Nat Commun. 2013;4. https://doi.org/10.1038/ncomms3126.

89. Duval K, Grover H, Han L-H, Mou Y, Pegoraro AF, Fredberg J, et al. Modeling physiological events in 2D vs. 3D cell culture. Physiology (Bethesda). 2017;32:266-77. https://doi.org/10. 1152/physiol.00036.2016.

90. Choi SW, Yeh YC, Zhang Y, Sung HW, Xia Y. Uniform beads with controllable pore sizes for biomedical applications. Small. 2010;6:1492-8.

91. Pothula SP, Xu Z, Goldstein D, Merrett N, Pirola RC, Wilson JS, et al. Targeting the HGF/c-MET pathway: stromal remodelling in pancreatic cancer. Oncotarget. 2017;8:76722-39.

92. Brandes F, Schmidt K, Wagner C, Redekopf J, Schlitt HJ, Geissler EK, et al. Targeting cMET with INC280 impairs tumour growth and improves efficacy of gemcitabine in a pancreatic cancer model. BMC Cancer. 2015;15:71.

93. Glodde N, Bald T, van den Boorn-Konijnenberg D, Nakamura K, O'Donnell JS, Szczepanski S, et al. Reactive neutrophil responses dependent on the receptor tyrosine kinase c-MET limit cancer immunotherapy. Immunity. 2017;47:789-802. e9

94. Finisguerra V, Conza G, Di, Matteo M, Di, Serneels J, Thompson AAR, Wauters E, et al. Europe PMC Funders Group Europe PMC Funders Author Manuscripts MET is required for the recruitment of anti-tumoural neutrophils. Nature. 2015;522:349-53.

95. Petterson SA, Dahlrot RH, Hermansen SK, Munthe S KA, Gundesen MT, Wohlleben $\mathrm{H}$, et al. High levels of c-Met is associated with poor prognosis in glioblastoma. J Neurooncol. 2015;122:517-27.

96. Hara T, Makino T, Yamasaki M, Tanaka K, Miyazaki Y, Takahashi T, et al. Effect of c-Met and CD44v6 expression in resistance to chemotherapy in esophageal squamous cell carcinoma. Ann Surg Oncol. 2019;26:899-906.

97. Lee CT, Chow NH, Su PF, Lin SC, Lin PC, Lee JC. The prognostic significance of RON and MET receptor coexpression in patients with colorectal cancer. Dis Colon Rectum. 2008;51:1268-74.

98. Jia L, Yang X, Tian W, Gou S, Huang W, Zhao W. Increased expression of c-Met is associated with chemotherapy-resistant breast cancer and poor clinical outcome. Med Sci Monit. 2018;24:8239-49.

99. Jiang WG, Grimshaw D, Lane J, Martin TA, Abounder R, Laterra $\mathrm{J}$, et al. A hammerhead ribozyme suppresses expression of hepatocyte growth factor/scatter factor receptor c-MET and reduces migration and invasiveness of breast cancer cells. Clin Cancer Res. 2001;7:2555-62.

100. Martin LP, Sill M, Shahin MS, Powell M, DiSilvestro P, Landrum LM, et al. A phase II evaluation of AMG 102 (rilotumumab) in the treatment of persistent or recurrent epithelial ovarian, fallopian tube or primary peritoneal carcinoma: a Gynecologic Oncology Group study. Gynecol Oncol. 2014;132:526-30.

101. Joffre C, Barrow R, Ménard L, Calleja V, Hart IR, Kermorgant S. A direct role for Met endocytosis in tumorigenesis. Nat Cell Biol. 2011;13:827-37.

102. Copin MC, Lesaffre M, Berbon M, Doublet L, Leroy C, Tresch $\mathrm{E}$, et al. High-MET status in non-small cell lung tumors 
correlates with receptor phosphorylation but not with the serum level of soluble form. Lung Cancer. 2016;101:59-67.

103. Hughes VS, Siemann DW. Have clinical trials properly assessed c-Met inhibitors? Trends Cancer. 2018;4:94.

104. Hughes VS, Siemann DW. Failures in preclinical and clinical trials of c-Met inhibitors: evaluation of pathway activity as a promising selection criterion. Oncotarget. 2019;10: 184-97.

105. Watermann I, Schmitt B, Stellmacher F, Müller J, Gaber R, Kugler C, et al. Improved diagnostics targeting c-MET in nonsmall cell lung cancer: expression, amplification and activation? Diagn Pathol. 2015;10:130. 